\title{
THE NUCLEAR INDUSTRY LEXICON IN THE CONTEMPORARY RUSSIAN POLITICAL DISCOURSE
}

\author{
Nataliya B. Feldman \\ Vladimir State University named after Alexander and Nikolay Stoletovs, Vladimir, Russia
}

\begin{abstract}
The present research has been conducted within the scope of such relevant direction of linguistics as functional lexicology, and is associated with the identification of semantic modifications of the word, which are conditioned by contextual features of its use. The adjectives atomic and nuclear became the object of the analysis: we give their characteristics in the lexical system of the Russian language, present the frequency of their use in different types of discourse, study more than 300 contexts of their use with nouns in the modern political discourse. The adjectives are studied in their direct and figurative meanings in neutral texts, as well as in pejorative (negative) and ameliotory (positive) contexts. It has been established that the Russian political discourse is characterized by prevailing use of adjectives atomic and nuclear in direct meaning. It has been revealed that the basis of metaphorization as the main way of creating figurative meanings of the adjectives in the political discourse is represented with such features as powerful release of energy, concentration, innovativeness, progress. We show the mechanism of leveling the pejorative axiological component of the phrase atomic bomb arising from its use in direct meaning and the appearance of ameliotory connotative meanings in the neutral phrase nuclear reactor. It has been found that the units under study are not recorded by lexicographic sources in figurative meanings, since they express an occasional sense in the political discourse.
\end{abstract}

Key words: nuclear industry lexicon, thematic lexicon, neutral connotation, ameliotory (positive) connotation, pejorative (negative) connotation, metaphorical transfer, change of lexical meaning, context.

Citation. Feldman N.B. The Nuclear Industry Lexicon in the Contemporary Russian Political Discourse. Vestnik Volgogradskogo gosudarstvennogo universiteta. Seriya 2, Yazykoznanie [Science Journal of Volgograd State University. Linguistics], 2018, vol. 17, no. 4, pp. 90-101. (in Russian). DOI: https://doi.org/10.15688/jvolsu2.2018.4.8

УДК 811.161 .1 '42

ББК $81.411 .2-51$

Дата поступления статьи: 27.07.2018 Дата принятия статьи: 27.08.2018

\section{ЛЕКСИКА АТОМНОЙ ОТРАСЛИ В СОВРЕМЕННОМ РУССКОЯЗЫЧНОМ ПОЛИТИЧЕСКОМ ДИСКУРСЕ}

\author{
Наталия Борисовна Фельдман \\ Владимирский государственный университет им. А.Г. и Н.Г. Столетовых, г. Владимир, Россия
}

\begin{abstract}
Аннотация. Исследование выполнено в русле такого актуального направления лингвистики, как функциональная лексикология, и связано с выявлением смысловых модификаций слова, обусловленных контекстуальными особенностями его использования. Объектом анализа стали прилагательные атомный и ядерный: дана их характеристика в лексической системе русского языка, представлена их частотность в разных типах дискурса, исследовано более 300 случаев употребления прилагательных атомный и ядерный в современном политичес$\infty$ ком дискурсе; рассмотрены прямые и переносные значения данных прилагательных в нейтральном тексте, в мелиоративных и пейоративных контекстах. Установлено, что в русскоязычном политическом дискурсе преобладает употребление прилагательных атомный и ядерный в прямом значении. Выявлено, что в основе метафоризации - основного способа создания переносных значений прилагательных атомный и ядерный в политическом дискурсе - лежат такие признаки, как «мощное высвобождение энергии», «концентрация», «инновационность», «движение вперед». Показан механизм нивелирования пейоративного оценочного компонента словосочетания атомная бомба, возникающего при его использовании в прямом значении, и появления мелиоративных коннотативных смыслов у нейтрального словосочетания ядерный реактор. Обнаружено, что исследу-
\end{abstract}


Н.Б. Фельдман. Лексика атомной отрасли в современном русскоязычном политическом дискурсе

емые единицы в переносных значениях не фиксируются лексикографическими источниками, поскольку в политическом дискурсе они выражают окказиональный смысл.

Ключевые слова: лексика атомной отрасли, тематическая группа лексики, нейтральная коннотация, мелиоративная коннотация, пейоративная коннотация, метафорический перенос, изменение лексического значения, контекст.

Цитирование. Фельдман Н. Б. Лексика атомной отрасли в современном русскоязычном политическом дискурсе // Вестник Волгоградского государственного университета. Серия 2, Языкознание. - 2018. - Т. 17, № 4. - C. 90-101. - DOI: https://doi.org/10.15688/jvolsu2.2018.4.8

\section{Введение}

Лексика атомной отрасли представляет собой обширную группу единиц, включающую термины, профессионализмы, номинации технологических явлений и процессов, названия устройств, механизмов и их частей, а также отдельных свойств и характеристик таких машин. Эти единицы в переносном значении, возникшем как результат метафорических или метонимических переносов, находятся на периферии анализируемой тематической группы. Лексика отрасли отмечается в разных дискурсах, в том числе и в политическом, а именно - в речи общественных и политических деятелей.

Актуальность настоящего исследования определяется отсутствием монографического описания тематической группы лексики атомной отрасли и общеязыковых процессов, происходящих в этой группе: расширение или сужение лексического значения, его изменение путем метафорического или метонимического переносов, а также отражение этих изменений в устной и письменной речи. К настоящему времени проанализированы в отдельных аспектах только некоторые единицы этой тематической группы. Так, в монографии В.М. Лейчика охарактеризованы слова атом, токамак, МАГАТЭ [Лейчик, 2009, с. 32, 37, $61,66]$. М.К. Борисова провела сопоставительный анализ структурных моделей отдельных терминов атомной сферы (ядерная безопасность) в английском, французском и русском языках [Борисова, 2016, с. 119-121].

В центре нашего внимания находятся прилагательные атомный и ядерный, функционирующие в современном политическом дискурсе как в прямом, так и в переносном значениях. В качестве источника языкового материала использованы высказывания общественных и политических деятелей, опубликованные на официальном сайте Президента Российской Федерации (www.kremlin.ru), а также в СМИ за период с 2011 по 2017 годы. Анализу подвергнуты более 250 текстов, из них методом сплошной выборки извлечены 300 контекстов с различной коннотацией, в которых употреблены исследуемые прилагательные.

\section{Частотность употребления}

прилагательных атомный и ядерный

в разных дискурсах

В разное время прилагательные атомный и ядерный использовались в текстах с разной частотой, о чем свидетельствуют, например, данные «Нового частотного словаря русской лексики» О.Н. Ляшевской, С.А. Шарова, представленные в таблице 1 .

Варьирование частоты употребления прилагательных атомный и ядерный в разные периоды обусловлено экономическими и

Частотность употребления прилагательных атомный и ядерный

Таблица 1 в разных жанрах и в разные периоды, ipm

\begin{tabular}{|c|c|c|c|c|}
\hline \multirow[b]{2}{*}{ Период } & \multicolumn{2}{|c|}{ Атомный } & \multicolumn{2}{|c|}{ Ядерный } \\
\hline & $\begin{array}{c}\text { Художественная } \\
\text { литература }\end{array}$ & Публицистика & $\begin{array}{c}\text { Художественная } \\
\text { литература }\end{array}$ & Публицистика \\
\hline 1950-60-е гг. & 23,0 & 26,7 & 6,2 & 7,4 \\
\hline 1970-80-е гг. & 16,2 & 44,4 & 4,3 & 43,3 \\
\hline 1990-2000-е гг. & 12,0 & 38,2 & 7,0 & 68,1 \\
\hline $\begin{array}{c}\text { Общий индекс } \\
\text { частотьл }\end{array}$ & \multicolumn{2}{|c|}{32,4} & \multicolumn{2}{|c|}{43,1} \\
\hline
\end{tabular}


общественно-политическими причинами. Так, 50-60-е гг. XX в. - время зарождения и развития атомной отрасли в Советском Союзе, когда были созданы первые ядерные реакторы и первые атомные бомбы, в 1954 г. заработала первая в мире Обнинская атомная электростанция. Успехам в сфере мирного атома и незасекреченным военным технологиям посвящались газетные статьи и художественные произведения.

Увеличение частоты встречаемости прилагательных атомный и ядерный в публицистике в период 1970-1980 гг. и 1990-2000 гг. обусловлено, на наш взгляд, тем, что 26 апреля 1986 г. произошла авария на Чернобыльской АЭС, которая вызвала широкий общественный резонанс в конце 80-х гг. ХХ в. и привлекает внимание СМИ в настоящее время. Дата аварии является особым информационным поводом, способствующим росту количества публикаций, в которых использованы анализируемые нами единицы. Значительное повышение частотности употребления прилагательного ядерный в публицистических текстах 1990-2000 гг. может быть связано как с развитием темы аварии на АЭС (Чернобыльской, Фукусимской), так и с обсуждением темы ядерного разоружения, активно освещавшейся в средствах массовой информации в 1990-е годы.

Из таблицы видно, что прилагательное ядерный в художественной литературе всех указанных периодов употребляется реже по сравнению с лексемой атомный, что может быть связано со следующими факторами:

- прилагательное атомный в большей степени ассоциировалось с мирными технологиями (атомные электростанции), а ядерный с военными (ядерные бомбы, ядерные взрывы);

- военные технологии всегда засекречены и, следовательно, упоминаются в публицистической и художественной литературе нечасто.

\section{Прилагательные атомный и ядерный \\ в лексикографических источниках}

1. В «Толковом словаре русского языка» С.И. Ожегова (включая издания в соавторстве с Н.Ю. Шведовой) прилагательное атомный как самостоятельная единица, которой посвящена отдельная словарная статья, не зафиксировано, однако представлен целый ряд однокоренных слов (атом, атомистический, атомник, атомоход, атомщик) (Ожегов, с. 38). У прилагательного ядерный отмечено три значения: 1. см. ядро. 2. Относящийся к процессам, происходящим в атомном ядре (спец.). Я. реактор. Ядерная энергия. Ядерное топливо. Ядерная физика. 3. Относящийся к ядерному оружию, обладающий этим оружием. Я. век. Я. арсенал. Ядерная держава. Ядерное разоружение (Ожегов, с. 734).

2. В «Большом толковом словаре русского языка» у прилагательных атомный и ядерный, помимо двух основных значений, уже фиксируется дополнительное значение: у прилагательного атомный со стилистической пометой «разг.», у прилагательного ядерныци со стилистической пометой «жарг.»:

Атомный, -ая, -ое. 1. к Атом. Атомное ядро. А. номер (порядковый номер химического элемента в периодической системе Менделеева). Относительная атомная масса (отношение массы атома элемента к 1/12 массы атома углерода). $A$-ая энергия (=ядерная). 2. Связанный с высвобождением и использованием ядерной энергии. $A$-ая электростанция (работающая на ядерном топливе). А. ледокол (ледокол-атомоход). A-ое оружие (ядерное оружие). $A$-ая война (ядерная война). 3. Разг. Ошеломляющий, потрясающий. $А$-ая смесь (о чем-л. совершенно несовместимом). Анекдот просто а.! A-ble иены (непомерно высокие) (БТСРЯ, с. 51).

Ядерный, -ая, -ое. 1. к Ядро (2, 4 зн.). Я-ая оболочка. Я-ая траектория. Я-ая вмятина. Я-ая часть клетки. 2. Относящийся к процессам, происходящим в атомном ядре, к использованию энергии атомного ядра. Я-ая реакииия. Я-ая энергия. Я-ое топливо. Я-ое оружие. Я. взрыв. Я-ая катастрофа. Я. реактор (устройство, в котором осуществляется управляемая цепная реакция деления атомных ядер). Я-ая физика (раздел физики, в котором изучаются атомные ядра и их превращения). \| Обладающий ядерным оружием. Я-ые страныl. Я-ая подводная лодка. 3. Жарг. Чрезмерный, крайний в своем проявлении. Я-ble иены (очень высокие). Я. плаш (сверхмодный) (БТСРЯ, с. 1531). 
Н.Б. Фельдман. Лексика атомной отрасли в современном русскоязычном политическом дискурсе

3. В «Толковом словаре русского языка конца XX века» указанные прилагательные не зафиксированы. Специфика этого словаря заключается в подробном описании наиболее употребительной лексики русского языка периода 1985-1997 гг. и динамических языковых процессов, остающихся за рамками классических толковых словарей. Несмотря на увеличение частотности употребления прилагательных атомный и ядерный в указанный период, анализируемые прилагательные не стали предметом внимания составителей словаря, что, возможно, связано либо с узкой сферой их употребления, либо с отсутствием динамических языковых процессов в анализируемый период, в частности, расширения / сужения лексического значения, а также метафорических и метонимических переносов.

4. В «Толковом словаре начала XXI века» прилагательное атомный отсутствует, а прилагательное ядерный фиксируется в составе словосочетания ядерный чемоданчик и в устойчивом выражении держать палеч на ядерной кнопке (ТСРЯ, с. 1107). Существующая отсылка к существительному чемоданчик фиксирует следующее лексическое значение:

Чемоданчик. Ядерный чемоданчик (находящееся у главы государства устройство, сигналом с которого санкционируется нанесение ответного ядерного удара) (ТСРЯ, с. 1067).

Значение глагола держать трактуется следующим образом:

Держать. Держать палец на ядерной кнопке (быть готовым к нанесению ядерного удара) (ТСРЯ, с. 300).

Выражая значение, зафиксированное третьим в словаре С.И. Ожегова, прилагательное ядерный в составе приведенных словосочетаний получает дополнительную смысловую нагрузку, что отражено в толковании, приведенном в скобках: наличие полномочий использования ядерного оружия, готовность к его применению.

5. В «Большом академическом словаре русского языка» зафиксировано три значения слова атомный: 1. Относящийся к атому, связанный с ним. 2. Связанный с исследованием атома. 3. Связанный с использованием энергии распада ядра атома (БАСРЯ, с. 304).

6. В «Активном словаре русского языка» фиксируются шесть лексем прилагатель- ного атомный, значения которых отражены и в других лексикографических источниках. В соответствии со спецификой словаря в словарной статье, посвященной вокабуле атомный, приведены примеры расширения значения и метонимического переноса лексемы атомный 2.3: «Такой, в котором используется или перерабатывается энергия, освобождающаяся при распаде ядер атомов» (АСРЯ, с. 123). Авторы, во-первых, отмечают, что расширенные употребления словосочетаний с лексемой атомный в вышеуказанном значении наблюдаются в период, когда атомная энергетика и ядерные технологии начали использоваться в медицине, сельском хозяйстве и других отраслях, и приводят в качестве примера словосочетания атомный век и атомная эра, во-вторых, выделяют метонимическое употребление прилагательного атомный применительно к явлениям, процессам, устройствам и т. п., связанным с разработкой и применением ядерного оружия: атомные испытания, атомный гриб, атомная война, атомная бомбардировка, атомное бомбоубежище, атомная стратегия и т. п. (АСРЯ, c. 123).

Лексические значения прилагательных атомный и ядерныій, зафиксированные в лексикографических источниках, реализуются в различных текстах и дискурсах, в том числе в высказываниях политических деятелей.

\section{Общая характеристика}

\section{прилагательных атомный и ядерный} в русскоязычном политическом дискурсе

Словосочетания с прилагательными атомный и ядерный в речи российских политических деятелей в XXI в. используются как в прямом, так и в переносном значениях, при этом текст может быть нейтральным, а может иметь мелиоративную или пейоративную коннотации. Как справедливо указывает Т.В. Матвеева, слова, являющиеся частью терминологической системы, языковой коннотацией обладать не могут, за исключением случаев, когда используется отраслевой компонент [Матвеева, 2010, с. 155]; соответственно, в настоящей статье анализу подвергается коннотация контекста, в котором употребляются анализируемые нами языковые едини- 
цы. Под контекстом мы вслед за О.С. Ахмановой [Ахманова, 1966, с. 197] и Т.В. Матвеевой [Матвеева, 2010, с. 159] понимаем речевое окружение прилагательных атомный и ядерный, законченное речевое высказывание, позволяющее в полном объеме раскрыть содержание, функцию и особенности значения анализируемых нами языковых единиц. Мелиоративная коннотация контекста, в соответствии с определением О.С. Ахмановой, рассматривается как коннотация законченного речевого высказывания, придающая слову положительное экспрессивно-эмоционально-оценочное значение [Ахманова, 1966, c. 218]. Пейоративная коннотация контекста толкуется как коннотация законченного речевого высказывания, придающая слову отрицательное экспрессивно-эмоционально-оценочное значение [Ахманова, 1966, с. 303]. Оценка (мелиоративная и пейоративная) является, как указывает Т.В. Матвеева, важнейшим компонентом коннотации и может быть направлена на предмет речи, собеседника, ситуацию общения либо самого говорящего [Матвеева, 2010, с. 288].

Политический дискурс, формирующийся в политической коммуникации, демонстрирует процесс, в котором язык выступает «и как средство отражения политической деятельности, и как составляющая поля политики» [Человек и его дискурс..., 2014, с. 133], то есть политическая деятельность во многих случаях сводится к речевой деятельности. Соответственно, мелиоративная и пейоративная оценка в политическом дискурсе становится инструментом выражения соответствующей коннотации контекста и в некоторых случаях используются в качестве обозначения вектора политической деятельности либо отношения говорящего к сказанному.

В таблице 2 представлено процентное соотношение употребления лексики атомной отрасли в прямом и переносном значениях с различной коннотацией контекста.

Количественные данные свидетельствуют о том, что при употреблении словосочетаний с прилагательными атомный и ядерный в прямом значении большинство высказываний политических деятелей - это нейтральный текст либо контекст с мелиоративной коннотацией. Как правило, эти прилагательные используются в следующих речевых ситуациях: ответы на вопросы в рамках «прямой линии» с Президентом, поздравления с отраслевыми праздниками, юбилеями, тематические доклады.

\section{Употребление}

\section{прилагательных атомный и ядерный}

в прямом значении

\section{Нейтральные тексты}

(1) Д.А. Медведев, Президент Российской Федерации (2008-2012). Выступление на заседании Комиссии по модернизации и технологическому развитию экономики России, 27.06.2011.

Особое внимание ядерной отрасли. Россия, конечно, и дальше будет заниматься развитием ядерной энергетики, совершенствуя системы безопасности ядерных реакторов на станциях. Серьезные исследования нужно вести в области переработки ядерных отходов (Заседание...).

(2) С.В. Кириенко, генеральный директор госкорпорации «Росатом». Выступление на заседании Комиссии по модернизации и технологическому развитию экономики России, 27.06.2011.

Первое, и главное, на сегодняшний день: 1 гигаватт атомных электростанций - это, собственно, один блок атомной станции - предотвращает 4,6 миллиона тонн выбросов $\mathrm{CO}_{2}$ в год, то есть совокупно все атомные станции, работающие в мире, экономят 1700 миллионов тонн (Заседание...).

Прилагательные атомный и ядерный в анализируемых контекстах входят в состав

Таблица 2

\section{Употребление прилагательных атомный и ядерный} в речи политических деятелей, \%

\begin{tabular}{|l|c|c|c|c|}
\hline \multirow{2}{*}{ Тип значения } & \multicolumn{4}{|c|}{ Характер контекста } \\
\cline { 2 - 5 } & $\begin{array}{c}\text { Общее } \\
\text { употребление }\end{array}$ & $\begin{array}{c}\text { Нейтральный } \\
\text { текст }\end{array}$ & $\begin{array}{c}\text { Контекст } \\
\text { с мелиоративной } \\
\text { коннотацией }\end{array}$ & $\begin{array}{c}\text { Контекст } \\
\text { с пейоративной } \\
\text { коннотацией }\end{array}$ \\
\hline Прямое & 98 & 62,9 & 31,3 & 3,8 \\
\hline Переносное & 2 & - & 1,5 & 0,5 \\
\hline
\end{tabular}


Н.Б. Фельдман. Лексика атомной отрасли в современном русскоязычном политическом дискурсе

терминологических словосочетаний: ядерная отрасль, ядерная энергетика, ядерный реактор, ядерные отходы, атомная электростанциия, атомная станция. Эти словосочетания в прямом значении, будучи нейтральными единицами, встречаются в текстах, в которых представлены тактические и стратегические планы развития отрасли и их реализация, доклады о результатах деятельности и аналитические выводы. Ситуации употребления лексики атомной отрасли в русскоязычном политическом дискурсе не отличаются от ситуаций употребления терминологической лексики других технологических сфер.

\section{Контексты с мелиоративной конно- тацичей}

(3) В.В. Путин, Президент Российской Федерации. Поздравление работникам и ветеранам атомной промышленности. 28.09.2015.

Становление отечественной атомной отрасли, которой в нынешнем году исполняется 70 лет, во многом определило эффективное развитие национальной экономики, послевоенную историю нашей страны. Благодаря атомной промышленности был обеспечен ядерный паритет и обороноспособность государства, создана атомная энергетика, открылись уникальные возможности для освоения арктического региона, мощнейший импульс получила фундаментальная и прикладная наука. Сегодня необходимо неуклонно наращивать фундаментальные научные исследования, работать над повышением надежности и безопасности атомных объектов, активно участвовать в реализации космических программ, перспективных международных проектов, укреплять позиции России на мировых рынках, в глобальной конкуренции (Поздравление...).

В приведенной цитате мелиоративная коннотация контекста создается посредством:

- реализации структурной схемы высказывания «тезис - аргументы»: тезис о том, что становление отечественной атомной отрасли во многом определило развитие послевоенной экономики и истории страны, заключенный в первом предложении, сопровождается аргументами, подтверждающими выдвинутый тезис, во втором и третьем предложениях;

- словосочетаниями, построенными по модели «прилагательное + существительное», в которых зависимое слово имеет позитивную коннотацию, а главное слово представляет собой существительное, обозначающее активное действие, движение, процесс: эффективное развитие, уникальные возможности, мощчнейший импульс, перспективные международные проекты;

- наречиями образа действия активно, неуклонно, характеризующими развитие отрасли;

- глаголами открылись, получила, наращивать, работать, участвовать, укреплять и краткими страдательными причастиями обеспечен, создана, выражающими значение совершенного или совершаемого действия, направленного на созидание, приобретение;

- словосочетаниями обеспечен ядерныи nаритет, обороноспособность государства, надежность и безопасность атомHblx объектов, подчеркивающими безопасность атомных технологий.

В результате анализа употребления лексики атомной отрасли в прямом значении в контексте с мелиоративной коннотацией установлено, что речевая ситуация употребления лексики атомной отрасли в контексте с мелиоративной коннотацией - это, как правило, поздравления с отраслевыми праздниками, юбилеями, другими значимыми событиями; позитивная коннотация контекста обеспечивается темой высказывания и соответствующими ей речевыми средствами:

a) уникальность и современность атомных технологий (уникальный, эффективный, мошчнейший, перспективный);

б) безопасность атомной энергетики (фундаментальные научные исследования, надежность, безопасность);

в) непрерывность развития отрасли (неуклонно, активно);

г) Россия как носитель уникальных и эффективных технологий, разработанных атомной промышленностью.

Таким образом, политические деятели посредством использования лексических единиц атомной отрасли в прямом значении в контексте с мелиоративной коннотацией, с одной стороны, подчеркивают надежность, безопасность и инновационность атомных технологий, с другой стороны, формируют образ России как мощного государства, владеющего этими технологиями. 


\section{Контексты с пейоративной конно- тацией}

(4) В.В. Путин, Президент Российской Федерации. Прямая линия с Президентом. 15.06.2017.

Не хочется здесь ничего нагнетать, но специалисты знают, что, допустим, американские атомные подводные лодки дежурят на севере Норвегии, подлетное время ракет - 15 минут до Москвы, и мы должны понимать, что там происходит, видеть, что там происходит, мы должны этот берег защитить соответствующим образом, пограничную охрану обеспечить (Прямая линия...).

Пейоративной коннотации приведенного контекста способствует выражение отношения говорящего к предмету речи, переданное безличной глагольной формой с отрицательной частицей не в сочетании с инфинитивом (коннотация опасности, угрозы): не хочется здесь ничего нагнетать, с последующим перечислением фактов готовности американцев к возможной агрессии: подлетное время ракет 15 минут до Москвы. Однако пейоративность контекста нивелируется готовностью говорящего обеспечить безопасность, выраженной модальным словом должны и глагольными лексемами, представляющими цепочку связанных действий: фиксация угрозы (знают, дежурят) - ее осознание (понимать, видеть) - eе нейтрализация (защитить, обеспечить). ЛДПР.

(5) В.В. Жириновский, председатель партии

«Стамбул уничтожить очень легко: достаточно одну ядерную бомбу в пролив бросить, и его смоет. Это будет такое страшное наводнение, столб воды поднимется на 10-15 метров, и города не будет, а там 9 миллионов живет», - пояснил лидер либерал-демократов (Лента.ру).

Пейоративная коннотация контекста создается посредством глаголов отрицательного воздействия на объект и глаголов прекращения бытия (бросить ядерную бомбу в пролив; его [Стамбул] смоет; будет страшное наводнение; уничтожсть Стамбул; уничтожить легко; города не будет).

Обобщая проведенный анализ употребления лексики атомной отрасли с пейоративной коннотацией, следует отметить, что в указанных примерах с помощью языковых средств создается коннотация опасности, уг- розы, исходящей от внешнего источника либо по его вине, от которой нужно защищаться. При этом в высказывании В.В. Жириновского содержится прямое предложение стать именно таким источником опасности, а в высказывании В.В. Путина анализируются потенциальные угрозы, источником которых являются другие страны. Таким образом, позиция В.В. Путина как главного лица государства выглядит гораздо более нейтральной и взвешенной. В этом контексте Президент выступает как гарант безопасности граждан, политик, видящий возможные угрозы мирному существованию и знающий, как эти угрозы нивелировать. В свою очередь В.В. Жириновский, будучи оппозиционным политиком и не имея реальной власти, может позволить себе более рискованные высказывания для привлечения внимания к своей персоне либо для создания образа России как страны с мощным ядерным потенциалом, который она может применить в случае необходимости.

\section{Употребление}

\section{прилагательных атомный и ядерный в переносном значении}

Примеры использования лексических единиц атомной отрасли в переносном значении встречаются в российском политическом дискурсе редко, но они иллюстрируют тенденцию, зафиксированную в словаре С.А. Кузнецова: метафорический перенос происходит на основе таких признаков денотата, как мощь, энергия, высокая степень концентрации. Рассмотрим примеры использования терминов, содержащих прилагательные атомный и ядерный и употребленных в переносном значении. Все приведенные ниже примеры представляют собой индивидуальные авторские метафоры.

\section{Контексты с мелиоративной конно- тацией}

(6) - Интерес к сельскому хозяйству у государства будет расти. Хлеб - это такая же атомная бомба, которая защищает нас с вами, и защищает так же активно. Потому что продовольственная безопасность, как и государственная безопасность, поставлены у нас в стране вровень, - заявил депутат Госдумы ФС РФ Геннадий Кулик (Зинурова). 
В приведенном примере метафора основана на понимании важности, насущной необходимости для государства атомной бомбы как хлеба (ср. с русской пословицей Хлеб всему голова). При этом коннотация угрозы отсутствует, она нивелируется словами безопасность и защищает. Хлеб сопоставляется с атомной бомбой, главное назначение которой, по мысли говорящего, состоит в защите страны и гарантировании безопасности ее гражданам.

(7) «Владимирская область - одна из центральных областей. Нужно было заняться немножко рядом серьезных экономических вопросов. Ну если так сказать по-русски, встряхнуть область. Я иногда считаю, что я, как атомная бомба, свалилась с учетом тех изменений, новшеств, поддержки экономики, новых проектов, прихода инвесторов. Я далека от мысли что-то идеализировать», - заявила Светлана Орлова, губернатор Владимирской области (Ростовцев).

В данном высказывании за основу метафорического переноса принимаются такие свойства номинируемого объекта, как концентрация энергии, мощь, сила. Губернатор Владимирской области Светлана Орлова сравнивает себя с атомной бомбой, потому что видит свою задачу в том, чтобы встряхнуть область, причем в позитивном смысле, и этот смысл создается с помощью однородных дополнений, в функции которых выступают слова с положительной коннотацией: изменений, новществ, поддержки экономики, новых проектов, прихода инвесторов. Сравнительный оборот свалилась, как атомная бомба может ассоциироваться с фразеологизмом упасть (свалиться) как снег на голову с общим значением внезапности, неожиданности. Для говорящего эта внезапность и неожиданность, непредвиденность происходящего связаны с желанием решить серьезные экономические задачи и привнести новшества в экономику области. Это высказывание отнесено нами к группе контекстов с мелиоративной коннотацией, так как, во-первых, словосочетание атомная бомба употребляется автором высказывания как собственная характеристика и определяет положительные действия и процессы, которые начали происходить после назначения С.Ю. Орловой на должность губернатора Владимирской области и которые она перечисляет сразу же после сравнения себя с атомной бомбой. Следовательно, мы можем говорить о наличии мелиоративной оценки, направленной на говорящего и его деятельность, создающей основной контекст анализируемого речевого высказывания.

(8) В.В. Путин, Президент Российской Федерации.

Но возникает вопрос: если мы существуем более 1000 лет, так активно развиваемся и укрепляем себя, значит, что-то у нас есть такое, что этому способствует. Это что-то - это внутренний «ядерный реактор» нашего народа, нашего человека, русского человека, российского человека, который позволяет двигаться вперед. Это некая пассионарность, о которой Гумилев говорил в свое время, которая толкает нашу страну вперед (Открытый урок...).

Основой метафорического переноса являются такие признаки, как наличие мощной энергии, необходимой для движения вперед, надежность и одновременно инновационность. Говоря о внутреннем «ядерном реакторе» русского человека, русского народа, В.В. Путин упоминает пассионарность как неуклонное стремление двигаться вперед. Важно подчеркнуть, что эту метафору В.В. Путин употребил, выступая перед российскими школьниками онлайн на открытом уроке «Россия, устремленная в будущее». Постановку кавычек можно объяснить индивидуальным характером авторской метафоры, которую говорящий осознает.

Анализ русскоязычного политического дискурса, в котором термины атомной отрасли употребляются в переносном значении в контексте с мелиоративной коннотацией, показал, что:

- словосочетание атомная бомба, обозначающее устройство с колоссальным разрушающим и поражающим эффектом, в XXI в. в речи российских политиков начинает приобретать новое, метафорическое значение, в основу которого положены признаки «безопасность», «защита», «энергия», «мощь», «инновационность», «тотальность»; при этом традиционный пейоративный оценочный компонент указанного словосочета- 


\section{РАЗВИТИЕ И ФУНКЦИОНИРОВАНИЕ РУССКОГО ЯЗЫКА}

ния нивелируется общей мелиоративной коннотацией контекста;

- мелиоративная коннотация контекста создается посредством метафорического переноса, который актуализирует позитивную черту у сравниваемого с атомной бомбой понятия: хлеб как основа продовольственной безопасности страны, особенности личности говорящего, воплощающей энергию движения вперед, изменения и развитие;

- словосочетание ядерный реактор используется как метафора, которая обозначает внутреннюю энергию, способствующую развитию, и может быть употреблено говорящим по отношению как к отдельному человеку, так и к народу в целом. Мелиоративная коннотация создается в результате использования лексических единиц, обозначающих движение вперед, развитие.

\section{Контекст с пейоративной конно- тацичей}

(9) Г.А. Зюганов, председатель Центрального комитета КПРФ.

Жилье хрущевской эпохи - это почти 40 процентов российского жилого фонда. Оно было рассчитано на 30, максимум на 40 лет, простояло же все 50-60. Если его сейчас не обновлять и не реконструировать, то через 10 лет оно все превратится в аварийное, и тогда эта жилищно-коммунальная «атомная бомба» взорвется неизбежно (Зюганов).

В приведенном примере основой метафорического переноса стал признак «концентрация энергии», но употребленное в контексте неизбежного коммунального коллапса словосочетание атомная бомба создает пейоративную коннотацию, которая усиливается в высказывании словами со значением «разрушение» (аварийное, взорвется), а также глаголами, выражающими положительное воздействие на объект, но употребленными с отрицательной частицей не (не обновлять, не реконструировать).

Появление авторских метафорических переносов, связанных с использованием терминов атомной отрасли, обусловлено, по-видимому, экстралингвистическими факторами. Одним из них может быть информационная политика государственной корпорации по атомной энергии «Росатом». Некоторые из ее принципов, реализованные в течение последних десяти лет, включают в себя максимально возможную прозрачность и открытость в вопросах применения атомных технологий в разных сферах, достоверность и оперативность информации, размещение в свободном доступе (онлайн) показателей уровня радиоактивности на территории предприятий атомной отрасли.

\section{Выводы}

1. Лексические единицы исследуемой тематической группы в русскоязычном политическом дискурсе употребляются преимущественно в прямом значении в нейтральных текстах, мелиоративных или пейоративных контекстах, при этом специфики, связанной с употреблением слов именно этой тематической группы в указанных видах текста и контекста, не выявлено. Прилагательные атомныци и ядерныци в составе словосочетаний употребляются аналогично лексемам, относящимся к тематическим группам профессиональной лексики других отраслей.

2. Мелиоративная коннотация контекста при употреблении лексем атомный и ядерный в прямом значении создается посредством насыщения речи прилагательными уникальныци, эффективныци, мошнейшиц̆, инновационный, перспективный, приоритетный, высокотехнологический; существительными исследования, надежность, безопасность, лидер (технологий), обороноспособность, возможности; наречиями образа действия неуклонно активно, бурно; в результате этого формируется образ России как страны, владеющей уникальными и инновационными технологиями.

3. Особенности построения русскоязычного политического дискурса с пейоративной коннотацией, в котором прилагательные атомный и ядерный используются в прямом значении, заключаются в следующем: во-первых, при выражении официальной позиции России по вопросам, касающимся использования ядерных технологий (в том числе военных) преобладает тема внешней угрозы, к которой Россия готова; при этом политики, представляющие оппозиционные партии (в частности, 
Н.Б. Фельдман. Лексика атомной отрасли в современном русскоязычном политическом дискурсе

В.В. Жириновский), создают образ России как внешнего агрессора, способного решить конфликт военным путем; во-вторых, высказывания, содержащие атомную лексику (в том числе заявления Президента РФ В.В. Путина), построены по схеме «тезис - аргументы вывод», помогающей изложить позицию говорящего в виде взвешенной позиции, общая идея которой выражается в наличии внешней угрозы и готовности ей противостоять. Пейоративная коннотация контекста создается в результате использования глаголов и прилагательных, выражающих значения отрицательного воздействия на объект, прекращения бытия, отрицательных эмоций и др.

4. Переносные значения терминов атомной отрасли, включающих прилагательные атомный и ядерныцй, создаются в результате метафоризации, в основе которой лежат такие признаки, как «мощное высвобождение энергии», «концентрация», «инновационность», «движение вперед». В проанализированных примерах нивелируется пейоративный оценочный компонент словосочетания атомная бом$\sigma a$, возникающий при его употреблении в прямом значении, и создается мелиоративная коннотация словосочетания ядерный реактор. В примере с пейоративной коннотацией контекста пейоративная оценка словосочетания атомная бомба используется автором высказывания как средство усиления контекстуальной коннотации. Выявленные переносные значения не фиксируются современными лексикографическими источниками.

5. Подобное словоупотребление и использование метафорического переноса применительно к лексике атомной отрасли в современном русскоязычном политическом дискурсе может быть связано, по нашему мнению, с информационной политикой Государственной корпорации по атомной энергии «Росатом» последних 10 лет, нацеленной на максимальную открытость и прозрачность в вопросах, касающихся применения атомных технологий, уровня радиоактивности в регионах, присутствия предприятий атомной отрасли.

\section{СПИСОК ЛИТЕРАТУРЫ}

Ахманова О. С., 1966. Словарь лингвистических терминов. М. : Советская энциклопедия. 608 с.
Борисова М. К., 2016. Сопоставительный анализ терминов международной безопасности в английском, французском и русском языках (на примере тематических областей «ядерная безопасность» и «информационная безопасность») // Вестник Московского государственного областного университета. Серия: Лингвистика. № 1. С. 118-127.

Лейчик В. М., 2009. Люди и слова: Как рождаются и живут слова в русском языке/ отв. ред. Г. В. Степанов. 2-е изд., испр. и доп. М. : Книжный дом «ЛИБРОКОМ». $216 \mathrm{c}$.

Матвеева Т. В., 2010. Полный словарь лингвистических терминов. Ростов н/Д : Феникс. 562 с.

Человек и его дискурс..., 2014. Человек и его дискурс-4 : коллектив. моногр. / отв. ред. М. Р. Желтухина. М. : ИЯ РАН : Издат. центр «Азбуковник». 398 с.

\section{ИСТОЧНИКИ}

Лента.ру - Жириновский предложил уничтожить Стамбул ядерным ударом // «Лента.ру». 27.11.2015. URL: https://lenta.ru/news/2015/11/ 27/zhirinovski/.

Заседание... - Заседание Комиссии по модернизации и технологическому развитию экономики России. 27.06.2011. URL: http://kremlin.ru/ events/president/news/11755.

Зинурова - Зинурова Е. Депутат Госдумы Геннадий Кулик: «Хлеб - это такая же атомная бомба» // Телеканал «Губерния33». 03.04.2017. URL: http://trc33.ru/news/society/deputatgosdumy-gennadiy-kulik-khleb-eto-takaya-zheatomnaya-bomba/.

Зюганов - Зюганов Г. А. Оружие против кризиса в программе КПРФ. 17.08.2017. URL: https:// kprf.ru/party-live/cknews/167853.html.

Открытый урок... - Открытый урок «Россия, устремленная в будущее». 01.09.2017. URL: http:// kremlin.ru/events/president/news/55493.

Поздравление... - Поздравление работникам и ветеранам атомной промышленности. 28.09.2015. URL: http://kremlin.ru/events/president/news/ 50381.

Прямая линия... - Прямая линия с Президентом. 15.06.2017. URL: http://kremlin.ru/events/ president $/$ news $/ 54790$.

Ростовиев - Ростовцев И. Хроники Светланы Орловой. Неделя № 9: «Я, как атомная бомба, свалилась на область» // Информационный портал «ПроВладимир». 21.05.2017. URL: https://provladimir.ru/news/vlast/hronikisvetlany-orlovoj-nedelya-9-ya-kak-atomnayabomba-svalilas-na-oblast. 


\section{СЛОВАРИ}

АСРЯ - Активный словарь русского языка / В. Ю. Апресян [и др.] ; отв. ред. Ю. Д. Апресян. М. : Языки славянской культуры, 2014. Т. 1. 408 с.

БАСРЯ - Большой академический словарь русского языка / гл. ред. К. С. Горбачевич. М. ; СПб. : Наука, 2004. Т. 1. 662 с.

БТСРЯ - Большой толковый словарь русского языка / сост. и глав. ред. С. А. Кузнецов. СПб. : Норинт, 2000. $1536 \mathrm{c}$.

Ожегов - Ожегов С. И. Толковый словарь русского языка / под ред. проф. Л. И. Скворцова. 27-е изд., испр. и доп. М. : ООО «Издательство «Мир и Образование», 2016. $736 \mathrm{c}$.

Толковый словарь русского языка конца XX века. Языковые изменения / под ред. Г. Н. Скляревской. СПб. : Фолио-Пресс, 1998. 700 с.

ТСРЯ - Толковый словарь русского языка начала XXI века. Актуальная лексика / под ред. Г. Н. Скляревской. М. : Эксмо, 2007. 1136 с.

\section{REFERENCES}

Akhmanova O.S., 1966. Dictionary of Linguistic Terms. Moscow, Sovetskaya entsiklopediya Publ. 608 p.

Borisova M.K., 2016. Comparative Analysis of International Security Terms in the English, French and Russian Languages (Case Study Based on Thematic Groups Nuclear Safety and Information Security). Vestnik Moskovskogo gosudarstvennogo oblastnogo universiteta. Seriya: Lingvistika [Bulletin of the Moscow Region State University. Series: Linguistics], no. 1, pp. 118-127.

Leychik V.M., 2009. People and Words: How Words Are Born and Live in the Russian Language. Moscow, LIBROKOM Publ. 216 p.

Matveeva T.V., 2010. Complete Dictionary of Linguistic Terms. Rostov-on-Don, Feniks Publ. 562 p.

Zheltukhina M.R. (ed.), 2014. Man and Their Discourse-4: Collective Monograph. Moscow, IYa RAN Publ.; Azbukovnik Publ. 398 p.

\section{SOURCES}

Zhirinovsky Proposed to Destroy Istanbul with a Nuclear Strike. Lenta.ru, November 27, 2015. URL: https://lenta.ru/news/2015/11/27/zhirinovski/.

Meeting of the Commission for Modernization and Technological Development of the Russian
Economy. June 27, 2011. URL: http://kremlin.ru/ events/president/news/11755.

Zinurova E. State Duma Deputy Gennadiy Kulik: "Bread and a Atomic Bomb Are Alike". Guberniya 33 TV Channel, April 3, 2017. URL: http://trc33.ru/news/society/deputat-gosdumygennadiy-kulik-khleb-eto-takaya-zhe-atomnayabomba/.

Zyuganov G.A. Arms against the Crisis - in the Program of the Communist Party of the Russian Federation. August 17, 2017. URL: https:// kprf.ru/party-live/cknews/167853.html.

Open Lesson "Russia Rushing to the Future". September 1, 2017. URL: http://kremlin.ru/ events/president/news/55493.

Congratulations to Employees and Veterans of the Nuclear Industry. September 28, 2015. URL: http://kremlin.ru/events/president/news/ 50381.

Phone-in with the President. June 15, 2017. URL: http:// kremlin.ru/events/president/news/54790.

Rostovtsev I. The Chronicles of Svetlana Orlova. Week 9: "I, Like an Atomic Bomb, Fell on the Region". Information Portal ProVladimir, May 21, 2017. URL: https://provladimir.ru/ news/vlast/hroniki-svetlany-orlovojnedelya-9-ya-kak-atomnaya-bomba-svalilasna-oblast.

\section{DICTIONARIES}

Apresyan V.Yu., Apresyan Yu.D., Babaeva E.E. (et al.). Active Vocabulary of the Russian Language. Moscow, Yazyki slavyanskoy kultury Publ., 2014, vol. 1. 408 p.

Gorbachevich K.S. (ed.). Big Academic Dictionary of the Russian Language. Moscow; Saint Petersburg, Nauka Publ., 2004, vol. 1. 662 p.

Kuznetsov S.A. (ed.). Big Explanatory Dictionary of the Russian Language. Saint Petersburg, Norint Publ., 2000. 1536 p.

Ozhegov S.I.. The Explanatory Dictionary of the Russian Language. Moscow, Mir i obrazovanie Publ., 2016. 736 p.

Dictionary of Russian language of the late twentieth century. Language changes / ed. G. N. Sklyarevskaya. $\mathrm{SPb}$. : Folio Press Publishing House, 1998. 700 p.

Sklyarevskaya G.N. (ed.), 2007. Explanatory Dictionary of the Russian Language of the Beginning of the $21^{\text {st }}$ Century. Up-to-Date Vocabulary. Moscow, Eksmo Publ. 1136 p. 
Н.Б. Фельдман. Лексика атомной отрасли в современном русскоязычном политическом дискурсе

\section{Information about the Author}

Nataliya B. Feldman, Postgraduate Student, Department of the Russian Language, Vladimir State University named after Alexander and Nikolay Stoletovs, Prosp. Oktyabrskiy, 3, 600000 Vladimir, Russia, nbfeldman@yandex.ru, https://orcid.org/0000-0002-0354-3778

\section{Информация об авторе}

Наталия Борисовна Фельдман, аспирант кафедры русского языка, Владимирский государственный университет им. А.Г. и Н.Г. Столетовых, просп. Октябрьский, 3, 600000 г. Владимир, Россия, nbfeldman@yandex.ru, https://orcid.org/0000-0002-0354-3778 